\title{
Composition and metabolism of the intestinal microbiota in consumers and non-consumers of yogurt
}

\author{
Elise Alvaro ${ }^{1}$, Claude Andrieux ${ }^{1}$, Violaine Rochet ${ }^{1}$, Lionel Rigottier-Gois ${ }^{1}$, Pascale Lepercq ${ }^{1}$, \\ Malène Sutren ${ }^{1}$, Pilar Galan ${ }^{2}$, Yvonne Duval ${ }^{1}$, Catherine Juste ${ }^{1}$ and Joël Doré ${ }^{1 *}$ \\ ${ }^{1}$ Unité d'Ecologie et de Physiologie du Système Digestif, Institut National de la Recherche Agronomique, 78352 Jouy-en-Josas, \\ France \\ ${ }^{2}$ Unité de Recherche en Epidémiologie Nutritionnelle, Institut National de la Santé et de la Recherche Médicale/Institut National de \\ la Recherche Agronomique/Conservatoire National des Arts et Métiers, CNAM, 5 rue Vertbois, 75003 Paris, France
}

(Received 12 April 2006 - Revised 8 August 2006 - Accepted 10 August 2006)

\begin{abstract}
The objective of the present study was to evaluate the impact of a regular consumption of yogurt on the composition and metabolism of the human intestinal microbiota. Adult subjects were selected on the basis of daily food records and divided into two groups: yogurt consumers (at least $200 \mathrm{~g}$ yogurt consumed per $\mathrm{d}, n$ 30); non-consumers (no yogurt, $n$ 21). Their faecal microbiota was analysed using molecular methods (in situ hybridisation and PCR amplification combined with separation by denaturing gel electrophoresis) and its metabolic characteristics were assessed by measuring glycosidase, $\beta$-glucuronidase and reductase activities and profiling SCFA, neutral sterols and bile acids. The yogurt starter Lactobacillus delbrueckii ssp. bulgaricus (identity confirmed by $16 \mathrm{~S}$ rRNA sequencing) was detected in $73 \%$ of faecal samples from fermented milk consumers v. $28 \%$ from non-consumers $(P=0 \cdot 003)$. In yogurt consumers, the level of Enterobacteriaceae was significantly lower $(P=0 \cdot 006)$ and $\beta$-galactosidase activity was significantly increased $(P=0.048)$. In addition, within this group, $\beta$-galactosidase activity and the Bifidobacterium population were both positively correlated with the amount of fermented milk ingested $(r 0 \cdot 66, P<0.0001$ and $r 0 \cdot 43, P=0 \cdot 018$, respectively). Apart from these effects, which can be considered beneficial to the host, no other major differences could be detected regarding the composition and metabolic activity of intestinal microbiota.
\end{abstract}

Fermented milk: Probiotics: Yogurt: Lactobacillus delbrueckii ssp. bulgaricus: Intestinal microbiota

Analysis of the human intestinal microbiota has rapidly evolved during the past 10 years (Tannock et al. 2000). Molecular techniques, based on detecting nucleotide sequences of 16S rRNA using fluorescent in situ hybridisation (FISH) and PCR amplification combined with separation by denaturing gel electrophoresis, have enabled a good assessment of the composition of the microbiota and the complexity of the dominant species present (Blaut et al. 2002). Moreover, these methods provide an opportunity to estimate the transient presence of food-borne bacteria within the predominant intestinal bacterial population (Alander et al. 1999; Tannock et al. 2000; Rochet et al. 2006).

Intestinal microbiota can induce both positive and negative effects on host physiology (Gorbach, 1986; Macfarlane \& Cummings, 1991) and there has been great interest in the feasibility of modulating intestinal microbiota in a beneficial way in order to improve health. In this field, lactic acid bacteria with probiotic properties have been considered as potentially useful (Shortt, 1999; Teitelbaum \& Walker, 2002; Guarner et al. 2005). Lactic acid bacteria have been used traditionally in food fermentation for thousands of years. Yogurt is milk fermented using a combination of Lactobacillus delbrueckii ssp. bulgaricus and Streptococcus salivarius ssp. thermophilus. More recently, other bacteria, mainly lactobacilli or bifidobacteria, have been combined with yogurt starters to produce fermented milks with specific functional properties related to health. Fermented milks deliver a large number of lactic acid bacteria into the gastrointestinal tract. These micro-organisms are capable of partially resisting gastric and bile secretions in vitro and in vivo (Mater et al. 2005) and can deliver enzymes and other substances into the intestines (Marteau \& Rambaud, 1993; Oozeer et al. 2002, 2005). The ability of yogurt to provide $\beta$-galactosidase and reduce symptoms of lactose intolerance has been well documented (Marteau \& Rambaud, 1993; Sanders, 1993). Lactic acid bacteria have also been claimed to modify the intestinal environment. Some studies have shown that L. acidophilus, L. casei and Bifidobacterium bifidum can decrease potentially harmful enzymes of the resident microbiota such as $\beta$-glucuronidase and nitroreductase (Goldin, 1986; Marteau et al. 1990; Guerin-Danan et al. 1998). These results were obtained during clinical trials involving volunteers who for a few

\footnotetext{
Abbreviations: FISH, fluorescent in situ hybridisation; TTGE, temporal temperature gradient gel electrophoresis analysis

* Corresponding author: Dr Joël Doré, fax +331346524 92, email joel.dore@jouy.inra.fr
} 
weeks consumed a controlled diet containing fermented milk, this period of consumption being compared with an initial period without these milk products.

The objective of the present study was to compare the composition and metabolism of the faecal microbiota in human subjects who regularly consumed at least $200 \mathrm{~g}$ yogurt per $\mathrm{d}$ or no yogurt. The effects of consuming dairy products on the dominant intestinal microbiota were evaluated using molecular approaches: in situ hybridisation and PCR amplification combined with separation by denaturing gel electrophoresis. Micro-organisms from fermented milk were monitored in faecal samples using specific primers. The following metabolic characteristics of the faecal microbiota were studied: glycosidases involved in carbohydrate hydrolysis $(\alpha-$ and $\beta$-galactosidase and $\beta$-glucosidase) and in mucin degradation (neuraminidase, $\mathrm{N}$-acetyl-galactosaminidase and $\alpha$-L-fucosidase), $\beta$-glucuronidase, nitrate and azoreductase activities as well as bile acid and neutral sterol microbial conversions. SCFA, $\mathrm{NH}_{3}$ and iso-acids were also investigated as markers of glycolytic and proteolytic fermentation.

\section{Materials and methods}

\section{Subjects}

Fifty-one healthy subjects living in the Paris area were included in the study. They were selected from the participants in the SU.VI.MAX cohort (Hercberg et al. 1998, 2004), who were providing regular information on their dietary intake by completing at least ten 24 -h record questionnaires over a period of 2.5 years. All subjects consumed their usual diet, with group $\mathrm{Y}$ containing subjects declaring an intake of 200-400 g yogurt per d (246 (SE 7)) and group N, non-consumers. Group Y included thirty individuals (aged 35-60 years, mean age 46 years, twelve males and eighteen females) while group $\mathrm{N}$ included twenty-one individuals (aged 35-60 years, mean age 47 years, nine males and twelve females), because of dietary habits in the Paris area where most people are used to consuming yogurt. In group $\mathrm{Y}$, the subjects regularly consumed soft white cheese (fromage blanc, 97 (SE 22) g/d) and in group $\mathrm{N}$, only occasionally (23 (SE 26) g/d) $(P=0.032)$. No differences were observed concerning the consumption of milk (82 (SE 21) and 67 (SE 25) g/d in groups $Y$ and $\mathrm{N}$, respectively, $P=0.642$ ) or cheese (46 (SE 10) and 38 (SE 11) $\mathrm{g} / \mathrm{d}$ in groups $\mathrm{Y}$ and $\mathrm{N}$, respectively, $P=0.594$ ).

Stools were collected once by each subject in sterile plastic containers and immediately frozen at $-20^{\circ} \mathrm{C}$ for subsequent analyses.

\section{PCR-temporal temperature gradient gel electrophoresis}

Total DNA was extracted as described previously (Suau et al. 1999) from $0 \cdot 25$-g aliquots of homogenised faeces or $2 \cdot 0-\mathrm{g}$ aliquots of yogurt and four fermented milks widely consumed in France. The concentration and integrity of nucleic acids were determined visually by electrophoresis on agarose $(10 \mathrm{~g} / \mathrm{l}) \mathrm{gel}$ containing ethidium bromide. Forward U968-GC (5'-CGC CCG GGG CGC GCC CCG GGC GGG GCG GGG GCA CGG GGG GAA CGC GAA GAA CCT TAC- $\left.3^{\prime}\right)$ and reverse T1401 (5'-GCG TGT GTA CAA GAC CC-3') primers were used to amplify the $\mathrm{V} 6$ to $\mathrm{V} 8$ regions of bacterial $16 \mathrm{~S}$
rDNA (Zoetendal et al. 1998). Primers Lac1 (5'-AGC AGT AGG GAA TCT TCC A-3 ${ }^{\prime}$ ) and Lac2GC (5'-CGC CCG CCG CGC GCG CGG CGG GCG GGG GCG GGG GCG GGG CAC GGG GGG ATT YCA CCG CTA CAC ATG-3') were used for specific amplification of the $16 \mathrm{~S}$ rDNA sequences of Lactobacillus, Pediococcus, Leuconostoc and Weissella genera, belonging to the Lactobacillus group (Walter et al. 2001). These two sets of primers produced 433 and $327 \mathrm{bp}$ PCR amplicons, respectively. All primers were purchased from Qbiogene Research Services (Evry, France). For the first set of primers, the PCR conditions were as described previously (Seksik et al. 2003). For the Lac1 and Lac2GC primers, the hybridisation temperature was $61^{\circ} \mathrm{C}$ for $1 \mathrm{~min}$. PCR products were analysed by electrophoresis on agarose $(10 \mathrm{~g} / \mathrm{l})$ gel containing ethidium bromide to check their size $(500 \mathrm{bp})$ and estimate their concentration. The DCode Universal Mutation Detection System (Bio-Rad, Paris, France) was used for the sequence-specific separation of PCR products, as previously described (Seksik et al. 2003). At the beginning of electrophoresis, for better resolution, the voltage was fixed at $20 \mathrm{~V}$ for $15 \mathrm{~min}$. Then, for the first set of amplicons, electrophoresis was run for $16 \mathrm{~h}$ at $64 \mathrm{~V}$ with initial and final temperatures of 66 and $70^{\circ} \mathrm{C}$, respectively (ramp rate $0 \cdot 2^{\circ} \mathrm{C}$ per $\mathrm{h}$ ). For amplicons obtained with primers Lac1 and Lac2GC, the initial and final temperatures were 63.8 and $70^{\circ} \mathrm{C}$, respectively (ramp rate $0.4^{\circ} \mathrm{C}$ per $\mathrm{h}$ ), at a voltage of $66 \mathrm{~V}$. Each well was loaded with 100-200 ng amplified DNA plus an equal volume of gel loading dye (bromophenol blue $(0.5 \mathrm{~g} / \mathrm{l})$-xylene cyanol $(0.5 \mathrm{~g} / \mathrm{l})$-glycerol $(700 \mathrm{~g} / \mathrm{l}))$. For each gel, three lanes were loaded with a marker obtained by mixing the PCR products of seven rDNA clones obtained from an adult male faecal sample (Suau et al. 1999). Clones were related to members of the Clostridium coccoides group, Clostridium leptum subgroup, Bacteroides group and Bifidobacterium genus. After the completion of electrophoresis, the gels were stained in the dark by immersion for $30 \mathrm{~min}$ in a solution of SYBR Green I Nucleic Acid Gel Stain (Roche Diagnostics, Meylan, France) and read on a Storm system (Molecular Dynamics, Amersham Biosciences, Orsay, France).

\section{Fluorescent in situ hybridisation combined with flow} cytometry

Whole cell FISH was performed as previously described (Rigottier-Gois et al. 2003) except that fixation was performed using frozen-thawed rather than fresh samples, within 1 month of collection (Rochet et al. 2004). The group-specific probes used are presented in Table 1. Data acquisition was performed using a Facs Calibur flow cytometer (Becton Dickinson, San Jose, CA, USA) equipped with an air-cooled Ar ion laser providing $15 \mathrm{~mW}$ at $488 \mathrm{~nm}$ combined with a $635 \mathrm{~nm}$ red diode laser (Rigottier-Gois et al. 2003). Subsequent analyses were conducted using CellQuest software (Becton Dickinson). Results were expressed as percentages of cells hybridising with the different group-specific probes relative to total bacteria hybridising with the EUB 338 probe, after the elimination of background fluorescence as determined using the NON 338 probe. Based on previous experience where faecal samples were added with serial dilutions of pure strains, the probes enabled the reliable detection of added target cells 
down to $0.5 \%$ of the total. However, when values below $0.5 \%$ were returned by the software, they were kept unchanged for the purposes of calculation.

\section{Biochemical analyses}

Enzyme activities were measured as previously described (Andrieux et al. 2002) using a thermo-regulated anaerobic chamber $\left(\mathrm{H}_{2}-\mathrm{CO}_{2}-\mathrm{N}_{2}(10: 10: 80\right.$, by vol.)). Frozen-thawed faecal samples were diluted 1:20 using pre-reduced PBS $(\mathrm{pH}$ 6.7). $\alpha$ - and $\beta$-galactosidase, $\beta$-glucosidase, $\beta$-glucuronidase, $\mathrm{N}$-acetyl-galactosaminidase and $\alpha$-L-fucosidase activities were measured by determining the rate of $p$-nitrophenol release from $p$-nitrophenyl glycosides. Azoreductase activity was determined using amaranth as the substrate. Neuraminidase activity was measured using 4-methylumbelliferyl$\mathrm{N}$-acetylneuraminic acid as the substrate. Nitrate reductase was determined by the generation of nitrite. Enzyme activities were expressed as $\mu \mathrm{mol}$ metabolised substrate per min and per g protein.

Protein concentrations were determined in triplicate using the method described by Lowry et al. (1951) with 1:500 faecal dilutions in $\mathrm{Na}_{2} \mathrm{CO}_{3}(20 \mathrm{~g} / \mathrm{l})$ and $\mathrm{NaOH}(0.1 \mathrm{M})$. Bovine serum albumin was used as the standard.

SCFA concentrations in faecal samples were analysed in duplicate after water extraction of acidified samples using GC (Perkin-Elmer 1020 GC; Perkin-Elmer, Saint Quentin, France) (Andrieux et al. 2002). $\mathrm{NH}_{3}$ was determined using the Berthelot method adapted by Drospy \& Boy (1961).

For bile acid analysis, the continuous extraction of 4 -g aliquots of homogenised faeces was carried out for $48 \mathrm{~h}$ using boiling ethanol $(100 \mathrm{ml})$ in a Soxhlet apparatus (Riottot et al. 1993). A 4-ml aliquot of the ethanol extract was hydrolysed by adding $1 \mathrm{ml} 10 \mathrm{M}-\mathrm{NaOH}$ and heating the alkaline mixture to $120^{\circ} \mathrm{C}$ for $3 \mathrm{~h}$ under pressure. The hydrolysate was then cooled to room temperature, diluted with an equal volume of water $(5 \mathrm{ml})$ and neutral sterols were extracted with $3 \times 10 \mathrm{ml}$ petroleum ether. The delipidated aqueous phase was then placed on ice, acidified to $\mathrm{pH} 2.0$ with concentrated $\mathrm{HCl}$ and bile acids were extracted with $3 \times 10 \mathrm{ml}$ ethylic ether. The combined solvent fractions containing either neutral or acidic sterols were evaporated to dryness and the samples were reconstituted in $2 \mathrm{ml}$ hexane or methanol, respectively, and analysed by GLC, taking $5 \alpha$-cholestane as the external standard.

\section{Statistical analyses}

PCR-temporal temperature gradient gel electrophoresis (TTGE) profiles were compared using GelCompar software (GelComparII $^{\mathrm{TM}}$ version 3.5; Applied Maths, Sint-MartensLatem, Belgium). Analysis included calculation of the number, position and intensity of PCR-TTGE bands (PCRamplified 16S rDNA fragments) in the gel. Pearson correlation provided similarity based upon densitometric curves. Pearson similarity coefficients were calculated to generate a similarity matrix. The dendrogram was obtained from this matrix using the Unweighted Pair Group Method using Arithmetic averages algorithm. Cell proportions as estimated by FISH and biochemical data were analysed using the general linear model procedure and the MEAN and LSMEAN statements in SAS 
Version 8.2 (SAS Institute, Cary, NC, USA) with one twolevel factor for comparison between yogurt consumers and non-consumers. Results were expressed as means and their standard errors and were considered significant at $P \leq 0 \cdot 05$. All data were examined for normal distributions and log-transformed when necessary prior to analysis. In this case, means were back-transformed for reporting as estimated means, and standard errors were estimated by assuming that standard errors on the logarithmic scale approximately equal $\mathrm{CV}$ on the actual scale. We employed Fisher's $R$-to- $z$ transformation and the CORR procedure under SAS to test whether correlations between yogurt consumption and different variables were significantly different from zero.

\section{Results}

\section{Composition of faecal microbiota}

Fluorescent in situ hybridisation analysis. Using FISH adapted for detection by flow cytometry, eight phylogenetic groups were investigated in faecal samples from yogurt consumers (Y) and non-consumers (N) (Fig. 1). The only significant difference concerned Enterobacteriaceae, which were found at significantly lower levels in group Y (0.3 (SE 0.3) \% v. 1.6 (SE 0.4) $\%$ in group $\mathrm{N}, P=0.006$ ). They were below the threshold of detection $(0.5 \%)$ in twenty-six out of thirty yogurt consumers, and between 0.5 and $2.4 \%$ in the remaining four. Among non-consumers, the levels of Enterobacteriaceae were below the detection threshold in twelve subjects while it ranged from 4.8 to $7.2 \%$ in four subjects. Interestingly, within group $\mathrm{Y}$, the proportion of bifidobacteria was positively correlated with fermented milk consumption $(r$ 0.43, $P=0.018)$. Overall, the cumulative proportions of cells hybridised with the eight group-specific probes among bacteria detected using the EUB 338 probe averaged 68.2 (SE 1.9) \%, without any significant difference between groups $\mathrm{Y}$ and $\mathrm{N}$.

PCR-temporal temperature gradient gel electrophoresis analysis. PCR-TTGE profiles obtained with general primers revealed the same broad inter-individual variability (Pearson similarity coefficient $<80 \%$ ) in both groups of

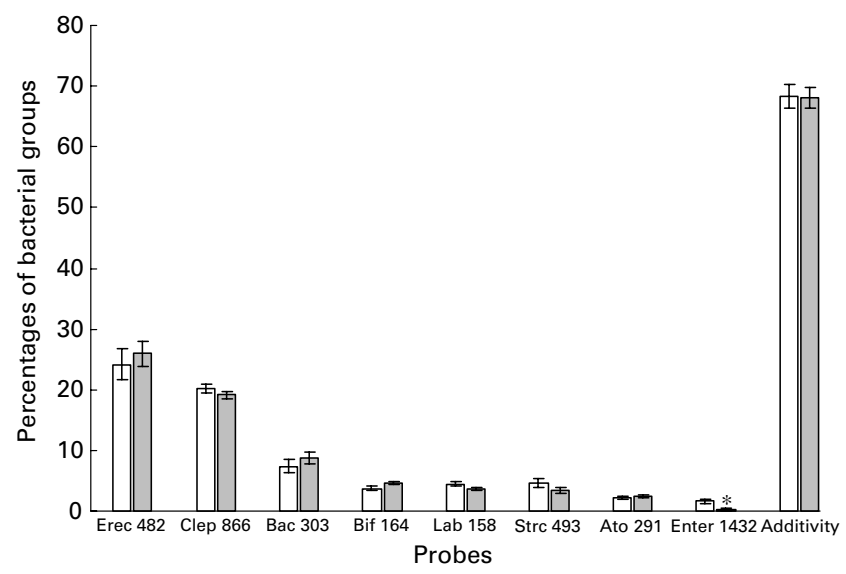

Fig. 1. Percentages of bacterial groups obtained by FISH analysis (see details in Table 1) in faecal samples from non-consumers (Group N, $\square$ ) and consumers of yogurt (Group $Y, \square$ ). Values are estimated means with their standard errors. *Indicates significant difference $(P=0.006)$ between mean values. subjects, without any significant differences between yogurt consumers and non-consumers. No band migrated at the same level as bands obtained from fermented milk (results not shown).

PCR-TTGE profiles generated with Lac1 and Lac2GC primers displayed no bands in three samples from group $\mathrm{N}$, while one to six bands were observed in the forty-eight remaining samples from groups $\mathrm{N}$ and $\mathrm{Y}$ (Fig. 2). One band co-migrating with that obtained from $L$. bulgaricus DNA was observed in $73 \%$ and $28 \%$ of samples from groups Y and $\mathrm{N}$, respectively $(P=0 \cdot 003)$. The PCR-TTGE profiles obtained with yogurt, three fermented milks and 'fromage blanc' revealed one band migrating at the same level (Fig. 3). Identity of L. bulgaricus was confirmed by sequencing the excised band from the gels of six yogurt consumers and from fermented milks. One band co-migrating with that obtained from $L$. casei DNA was obtained in four samples from group $\mathrm{Y}$ and one sample from group $\mathrm{N}$; L. bulgaricus was found together with $L$. casei in these profiles and in the profile of the fermented milk Actimel ${ }^{\circledR}$ (Danone, France). One band was identified as Leuconostoc mesenteroides in the fermented milk Yorik ${ }^{\circledR}$ (Yoplait, France) and in three samples from groups $\mathrm{Y}$ and $\mathrm{N}$. It is also interesting to note that TTGE analysis of fermented milks revealed a weaker band for the probiotic organism than for the starter organism.

\section{Metabolic activities}

Among the nine metabolic bacterial enzyme activities investigated, the only significant difference concerned $\beta$-galactosidase, which was found at significantly higher levels in group $\mathrm{Y}$ (Table 2). It was higher than $100 \mu \mathrm{mol} / \mathrm{min}$ per g protein in five yogurt consumers and higher than $200 \mu \mathrm{mol} / \mathrm{min}$ per $\mathrm{g}$ protein in two of them. Among non-consumers, this activity only reached $100 \mu \mathrm{mol} / \mathrm{min}$ per g protein in one subject while it was inferior to $50 \mu \mathrm{mol} / \mathrm{min}$ per g protein in five subjects. Moreover, in group $\mathrm{Y}, \beta$-galactosidase activity was positively correlated with the daily consumption of yogurt $(r 0.66$, $P<0 \cdot 0001)$.

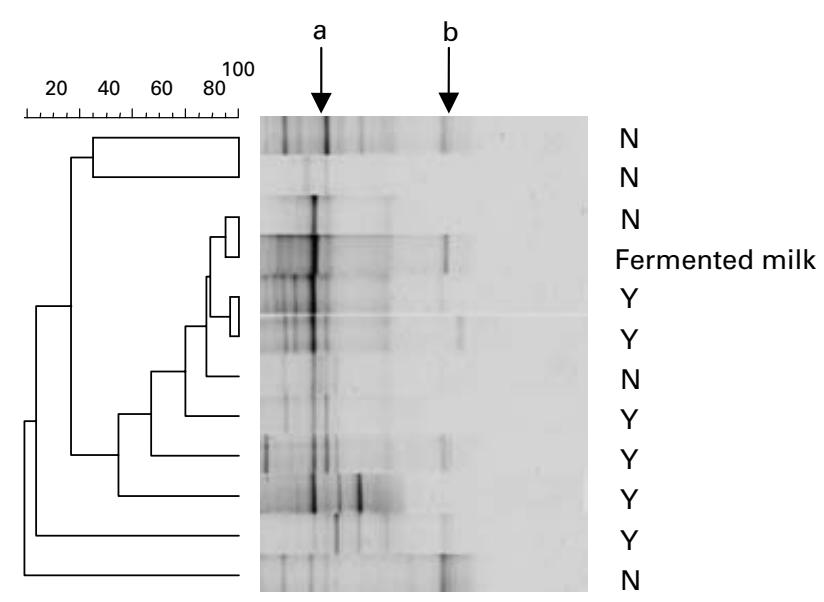

Fig. 2. PCR-TTGE profiles obtained with Lac1 and Lac2GC primers from faecal samples of non-consumers $(\mathrm{N})$ and consumers $(\mathrm{Y})$ of yogurt and from fermented milk containing yogurt starters and L. casei (Actimel ${ }^{\circledR}$, Danone, France). Arrows show L. delbrueckii subsp. bulgaricus (a) and L. casei (b). 


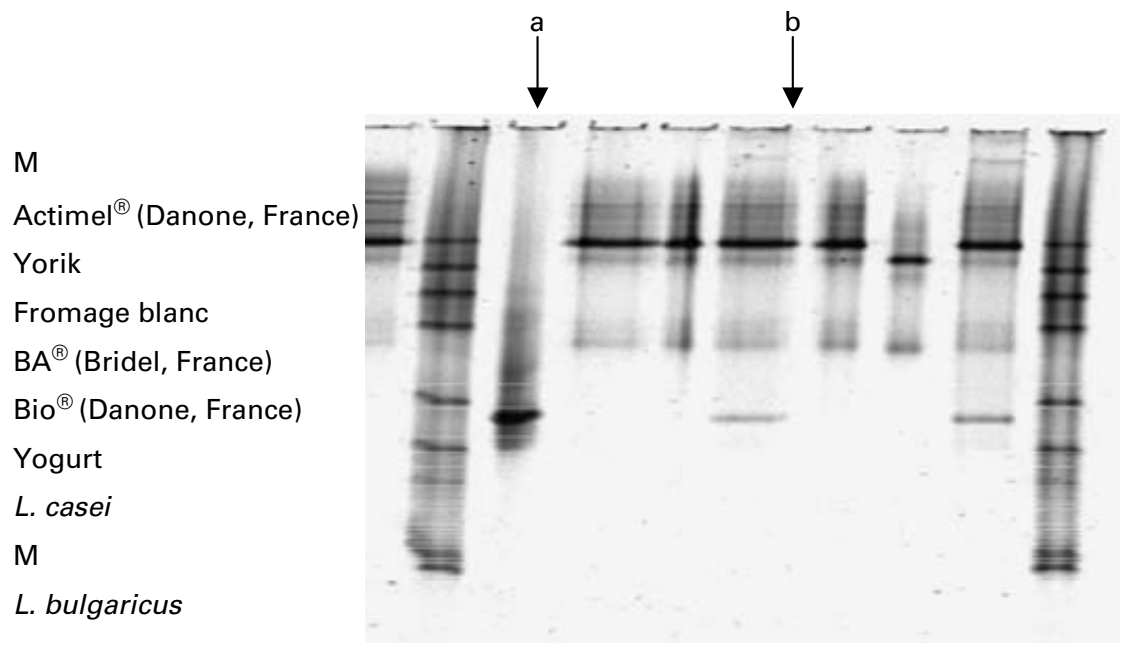

Fig. 3. PCR-TTGE profiles obtained with Lac 1 and Lac2GC primers from six dairy products, and from L. delbrueckii subsp. bulgaricus (a) and L. casei (b). M: marker obtained by mixing PCR products of seven rDNA clones (Suau et al. 1999).

The overall concentration of SCFA was about $100 \mu \mathrm{mol} / \mathrm{g}$ fresh faeces in both groups of subjects $(P=0 \cdot 151)$ without any significant inter-group difference in composition (Table 3). However, in group Y, $67 \%$ of values were superior to $100 \mu \mathrm{mol} / \mathrm{g}$ compared with $38 \%$ in group N. Moreover, the lowest values $(<40 \mu \mathrm{mol} / \mathrm{g})$ were all found in group $\mathrm{N}$.

Cholic and chenodeoxycholic acids are the two primary bile acids (i.e. synthesised by the liver) in man and physiologically are poorly represented in stools. Their respective proportions were less than $5 \%$ (mass percentage of total faecal bile acids, non-significant difference) in both groups of subjects (Table 4). All other bile acids are secondary bile acids, i.e. bacterial metabolites of cholic and chenodeoxycholic acids. They did not differ significantly between groups, except for 7-keto-lithocholic acid, which was found at lower levels $(P=0.012)$ in yogurt consumers (Table 4). Concomitantly, the proportion of ursodeoxycholic acid, which is the $7 \beta-\mathrm{OH}$ epimer of chenodeoxycholic acid with 7-keto-lithocholic acid as the intermediate reaction product, tended to be lower $(P=0 \cdot 078)$ in yogurt consumers. But the overall proportion

Table 2. Bacterial enzyme activities ( $\mu \mathrm{mol} / \mathrm{min}$ per g protein) in faecal samples from non consumers (group $\mathrm{N}$ ) or consumers (group $\mathrm{Y}$ ) of yogurt*

(Mean values with their standard errors)

\begin{tabular}{|c|c|c|c|c|c|}
\hline \multirow[b]{2}{*}{ Enzymes } & \multicolumn{2}{|c|}{$\begin{array}{c}\text { Group N } \\
(n 21)\end{array}$} & \multicolumn{2}{|c|}{$\begin{array}{c}\text { Group Y } \\
(n 30)\end{array}$} & \multirow[b]{2}{*}{$P$ value } \\
\hline & Mean & SE & Mean & SE & \\
\hline$\beta$-galactosidase & 68.90 & $2 \cdot 43$ & 85.43 & 2.51 & 0.048 \\
\hline$\alpha$-galactosidase & $20 \cdot 29$ & 1.75 & $21 \cdot 25$ & 1.46 & 0.678 \\
\hline$\beta$-glucosidase & 7.40 & 0.32 & $9 \cdot 18$ & 0.32 & $0 \cdot 100$ \\
\hline Neuraminidase & 1.78 & 0.10 & 1.51 & 0.08 & 0.341 \\
\hline $\mathrm{N}$-acetyl-galactosaminidase & 3.08 & $0 \cdot 18$ & $3 \cdot 28$ & $0 \cdot 16$ & 0.716 \\
\hline$\alpha$-L-fucosidase & $2 \cdot 08$ & 0.11 & $2 \cdot 30$ & $0 \cdot 10$ & 0.521 \\
\hline$\beta$-glucuronidase & $4 \cdot 20$ & 0.19 & $4 \cdot 20$ & $0 \cdot 16$ & 0.996 \\
\hline Nitrate reductase & $0 \cdot 10$ & 0.02 & 0.17 & 0.02 & 0.253 \\
\hline Azoreductase & 0.08 & 0.01 & 0.07 & 0.01 & 0.768 \\
\hline
\end{tabular}

${ }^{\star}$ For details of subjects and procedures, see pp. 127-128. of secondary bile acids did not significantly differ between groups (Table 4). Untransformed neutral sterols of animal and plant origin, i.e. cholesterol and $\beta$-sitosterol, each represented about $10 \%$ total neutral sterols in stools, without there being any significant difference between groups (Table 4). Nor were bacterial products of cholesterol (coprostanol, cholestanol and coprostanone) and $\beta$-sitosterol (copro- $\beta$-sitosterol) modified by yogurt consumption (Table 4 ).

\section{Discussion}

During the present study, molecular and biochemical approaches were used to assess the effects of fermented milk consumption when subjects were consuming selfchosen diets. The human volunteers were selected from participants in the SU.VI.MAX cohort (Hercberg et al. 2004). They either consumed at least $200 \mathrm{~g}$ yogurt per d or no fermented milk products at all. Their food records did not include the brand of the foods consumed; we therefore compared the profiles of faecal bacteria from subjects with those of the commercial products generally consumed in the Paris area where the subjects lived.

Table 3. Concentration of SCFA ( $\mu \mathrm{mol} / \mathrm{g}$ fresh stools) in faecal samples from non-consumers (group $\mathrm{N}$ ) or consumers (group $\mathrm{Y}$ ) of yogurt*

(Mean values with their standard errors)

\begin{tabular}{|c|c|c|c|c|c|}
\hline \multirow[b]{2}{*}{ SCFA } & \multicolumn{2}{|c|}{$\begin{array}{c}\text { Group N } \\
(\text { n 21) }\end{array}$} & \multicolumn{2}{|c|}{$\begin{array}{c}\text { Group } Y \\
(n 30)\end{array}$} & \multirow[b]{2}{*}{$P$ value } \\
\hline & Mean & SE & Mean & SE & \\
\hline Total & $92 \cdot 8$ & $7 \cdot 6$ & $107 \cdot 4$ & $6 \cdot 4$ & 0.151 \\
\hline Acetate & $61 \cdot 6$ & 1.6 & $60 \cdot 7$ & 1.3 & 0.667 \\
\hline Propionate & $16 \cdot 8$ & 0.3 & $17 \cdot 1$ & 0.3 & 0.773 \\
\hline Butyrate & $14 \cdot 6$ & $1 \cdot 1$ & $14 \cdot 3$ & $1 \cdot 0$ & 0.843 \\
\hline Iso-acids & 4.2 & 0.5 & $5 \cdot 0$ & 0.4 & 0.210 \\
\hline Valerate + caproate & $2 \cdot 3$ & 0.2 & $2 \cdot 7$ & 0.2 & $0 \cdot 168$ \\
\hline
\end{tabular}

${ }^{*}$ For details of subjects and procedures, see pp. 127-128. 
Table 4. Profiles of acidic and neutral sterols (mass percentages of total bile acids and neutral sterols) in faecal samples from non-consumers (Group N) and consumers (Group Y) of yogurt?

(Mean values with their standard errors)

\begin{tabular}{|c|c|c|c|c|c|}
\hline \multirow[b]{2}{*}{ Sterol } & \multicolumn{2}{|c|}{$\begin{array}{c}\text { Group N } \\
(n 21)\end{array}$} & \multicolumn{2}{|c|}{$\begin{array}{c}\text { Group } \mathrm{Y} \\
(n 30)\end{array}$} & \multirow[b]{2}{*}{$P$ value } \\
\hline & Mean & SE & Mean & $\mathrm{SE}$ & \\
\hline \multicolumn{6}{|l|}{ Acidic } \\
\hline Cholic & 4.23 & 0.44 & $2 \cdot 97$ & 0.26 & 0.269 \\
\hline Deoxycholic* & 44.87 & 2.40 & 48.03 & 1.86 & 0.303 \\
\hline Ursocholic* & $5 \cdot 15$ & 0.76 & 4.83 & 0.59 & 0.740 \\
\hline 7-keto-deoxycholic* & 0.43 & 0.17 & $0 \cdot 12$ & 0.13 & 0.169 \\
\hline Chenodeoxycholic & 4.30 & 0.39 & 3.15 & 0.24 & 0.263 \\
\hline Lithocholic $†$ & 33.39 & 1.44 & 34.57 & $1 \cdot 16$ & 0.785 \\
\hline Ursodeoxycholic $†$ & 3.92 & 0.50 & $2 \cdot 77$ & 0.39 & 0.078 \\
\hline 7-keto-lithocholic $\dagger$ & 4.93 & 0.59 & 2.95 & 0.46 & 0.012 \\
\hline Sum of secondary $\ddagger$ & $92 \cdot 13$ & 2.05 & 93.60 & 1.58 & 0.576 \\
\hline \multicolumn{6}{|l|}{ Neutral } \\
\hline Cholesterol & $13 \cdot 15$ & 1.89 & $9 \cdot 40$ & 1.47 & 0.128 \\
\hline Coprostanol§ & $26 \cdot 05$ & 1.21 & $26 \cdot 82$ & 0.96 & 0.830 \\
\hline Cholestanol§ & $1 \cdot 17$ & 0.26 & 1.07 & 0.20 & 0.756 \\
\hline Coprostanone§ & 1.37 & 0.41 & $2 \cdot 16$ & 0.32 & 0.140 \\
\hline$\beta$-sitosterol & 9.63 & 1.76 & 7.33 & 1.36 & 0.310 \\
\hline Copro- $\beta$-sistosterol|| & 49.12 & 2.93 & 52.93 & $2 \cdot 27$ & 0.313 \\
\hline
\end{tabular}

* Bacterial metabolites of cholic acid.

† Bacterial metabolites of chenodeoxycholic acid.

$\ddagger$ Deoxycholic + ursocholic +7-keto-deoxycholic + litocholic + ursodeoxycholic +7-keto-lithocholic.

$\S$ Bacterial metabolites of cholesterol.

|| Bacterial metabolite of $\beta$-sitosterol.

ๆ For details of subjects and procedures, see pp. 127-128.

Using group-specific primers for Lactobacillus and related genera with sequencing confirmation, L. delbrueckii ssp. bulgaricus was identified in four out of five commercial fermented milks, including yogurt, and in 'fromage blanc', which was also widely consumed in group Y. Using the same group-specific primers (which normally detect Lactobacillus species present at a level of $>10^{6}$ colony-forming units/g wet faeces), L. delbrueckii ssp. bulgaricus was also identified in $73 \%$ of faecal samples from yogurt consumers but in only $28 \%$ of faecal samples from non-consumers. L. casei was also identified in three times more yogurt consumers than non-consumers. Conversely, using non-specific primers (which detect the 90-99\% most numerous species in the community) did not allow us to highlight any faecal bacteria from fermented milk in any subjects. These results suggest that, in most yogurt consumers, L. delbrueckii ssp. bulgaricus was present at a level where biological effects could be expected (Marteau $\&$ Rambaud, 1993). This was also the case in a reduced proportion of non-consumers, all but one of whom were the highest consumers of cheese (but not of 'fromage blanc') within their group. Consumption of L. bulgaricus-containing cheeses, such as Swiss (Emmental, Gruyère) or Mediterranean (Feta, Mozzarella, Provolone, etc.), could therefore explain the occurrence of this micro-organism in group N. But it should be emphasised that the current results do not provide information on the survival of this micro-organism in faeces and a fortiori during transit in the gastrointestinal tract, since PCR-amplified DNA detection does not distinguish between live, injured and dead cells. Other studies have provided evidence that L. delbrueckii ssp. bulgaricus and L. casei, known to exhibit poor survival when challenged in vitro by gastric acidity and bile salts, partly survive transit through the gastrointestinal tract of human volunteers (Pochart et al. 1989; Bouhnik, 1993; Yuki et al. 1999; Callegari et al. 2004; Mater et al. 2005) and Göttingen minipigs (Lick et al. 2001) ingesting yogurt. Furthermore, there is recent evidence that L. casei initiates protein synthesis during its transit in the digestive tract of mice harbouring human intestinal microbiota (Oozeer et al. 2002, 2005) and that some protective effects of probiotics, such as immuno-stimulation, are mediated by their own DNA rather than by their ability to survive through the gastrointestinal tract (Rachmilewitz et al. 2004).

FISH analysis of the predominant bacterial groups in faeces showed that Enterobacteriaceae, which include pathogenic bacteria, were significantly less represented in yogurt consumers. Otherwise, chronic consumption of yogurt did not significantly alter other bacterial groups. But interestingly, within group $\mathrm{Y}$, values obtained for the Bifidobacterium genus, which is recognised for its potential health-promoting capacities (Gibson et al. 1995), was positively correlated with fermented milk consumption. Taken altogether, these novel results suggest that a regular consumption of yogurt in a self-chosen diet could induce modifications in the indigenous microbiota.

During the present study, $\beta$-galactosidase activity in faeces was found to be significantly increased in yogurt consumers and to exhibit a positive correlation with the amount of yogurt consumed within this group. In yogurt, $S$. salivarius ssp. thermophilus contains a $\beta$-galactosidase, which is active in the digestive tract of germ-free mice (Drouault et al. 2002), while L. delbrueckii ssp. bulgaricus does not (Pochart et al. 1989). This suggests that $S$. salivarius ssp. thermophilus may survive intestinal transit, even though overall levels of the streptococcus group did not significantly differ between subject groups. Other intestinal bacteria may also participate in lactose fermentation (He et al. 2005), e.g. bifidobacteria, the proportion of which presented a positive correlation with the amount of fermented milk consumed in group Y. Otherwise, chronic consumption of yogurt did not significantly alter other enzyme activities. This is in contrast with the reports of authors who have found that some probiotics, mainly lactobacilli or bifidobacteria, may improve bacterial metabolism by decreasing potentially harmful enzymes such as $\beta$-glucuronidase, reductases and $7 \alpha$-dehydroxylase (Rowland, 1992; Roos \& Katan, 2000). Because the SU.VI.MAX questionnaire did not allow a distinction between subjects who consumed traditional yogurts (fermented with $S$. thermophilus and $L$. delbrueckii ssp. bulgaricus starter cultures) and those who consumed yogurts enriched with other probiotic bacteria, it cannot be excluded that the differences between groups were only small because the study participants mainly consumed traditional yogurts.

Sterol metabolism was weakly affected by yogurt consumption, as inferred from the respective proportions of the different molecular species of neutral and acidic sterols in the stools of yogurt consumers and non-consumers. It has been argued that the bile salt hydrolase activity of ingested bacteria, such as lactobacilli and bifidobacteria, might favour the early deconjugation of bile acids in the small intestine and their subsequent biotransformation by the resident microbiota, leading to the increased formation of cytotoxic secondary bile acids 
(Marteau et al. 1995). This was not observed in the present study, where the overall percentages of secondary bile acids and of the main secondary lithocholic and deoxycholic acids, which are known to be the most cytotoxic, were not increased in yogurt consumers. The only difference concerned the minor secondary 7-keto-lithocholic acid, and to a lesser extent ursodeoxycholic acid, which were or tended to be decreased in yogurt consumers. This suggests that $7 \beta$-epimerisation of chenodeoxycholic to ursodeoxycholic acid, via 7keto-lithocholic acid as the intermediate product (Lepercq et al. 2004) could be decreased by long-term yogurt consumption. It is impossible to speculate as to the mechanisms involved or any impact on health.

In conclusion, the present work demonstrated the presence of food-borne bacteria in faeces from healthy volunteers who regularly included yogurt in their everyday diet in an industrialised country. It also suggests that the consumption of yogurt may ensure some advantageous changes to the equilibrium and metabolic activities of the indigenous microbiota.

\section{Acknowledgements}

We are grateful to C. Girard for her technical assistance, to O. David for statistical advice, to Dr. G. Corthier, Dr P. Langella and Dr. S. Rabot for helpful suggestions regarding the manuscript and to V. Hawken for her advice on English translation.

\section{References}

Alander M, Satokari R, Korpela R, Saxelin M, Vilpponen-Samena T, Mattila-Sandholm T \& von Wright A (1999) Persistence of colonization of human colonic mucosa by a probiotic strain, Lactobacillus rhamnosus GG, after oral consumption. Appl Environ Microbiol 65, 351-354.

Amann RI, Ludwig W \& Schleifer KH (1995) Phylogenetic identification and in situ detection of individual microbial cells without cultivation. Microbiol Rev 59, 143-169.

Andrieux C, Membre JM, Cayuela C \& Antoine JM (2002) Metabolic characteristics of the fecal microflora in humans from three age groups. Scand J Gastroenterol 7, 792-798.

Blaut M, Collins MD, Welling GW, Dore J, Van Loo J \& De Vos W (2002) Molecular biological methods for studying the gut microbiota: the E.U. human gut flora project. Brit J Nut 87, S203-S211.

Bouhnik Y (1993) Survie et effets chez l'homme des bactéries ingérées dans les laits fermentés [Survival and effects of bacteria ingested via fermented milks in humans]. Lait 73, 241-247.

Callegari ML, Morelli L, Ferrari SL, Cobo Sanz JM \& Antoine JM (2004) Yogurt symbiosis survived in human gut after ingestion. FASEB J 18, (Abstr 115.8).

Drospy G \& Boy J (1961) Détermination de l'ammoniémie (méthode automatique par dialyse) [Determination of ammonemia (automatic method using dialysis)]. Ann Biol Clin-Paris 19, 313-317.

Drouault S, Anba J \& Corthier G (2002) Streptococcus thermophilus is able to produce a $\beta$-galactosidase active during its transit in the digestive tract of germ-free mice. Appl Environ Microbiol 68, 938-941.

Franks AH, Harmsen HJM, Raangs GC, Jansen GJ, Schut F \& Welling G (1998) Variations of bacterial populations in human feces measured by fluorescent in situ hybridisation with group specific 16S-rRNA-targeted oligonucleotide probes. Appl Environ Microbiol 64, 3336-3345.
Gibson GR, Beatty ER, Wang X \& Cummings JH (1995) Selective stimulation of bifidobacteria in the human colon by oligofructose and inulin. Gastroenterology 108, 975-982.

Goldin BR (1986) The metabolism of the intestinal microflora and its relationship to dietary fat, colon, and breast cancer. Prog Clin Biol Res 222, 655-685.

Gorbach SL (1986) Function of the human normal microflora. Scand $J$ Infect Dis 49, 17-30.

Guarner F, Perdigon G, Corthier G, Salminen S, Koletzko B \& Morelli L (2005) Should yoghurt cultures be considered probiotic? Br J Nutr 93, 783-786.

Guerin-Danan C, Chabanet C, Pedone C, Popot F, Vaissade P, Bouley C, Szylit O \& Andrieux C (1998) Milk fermented with yogurt cultures and Lactobacillus casei compared with yogurt and gelled milk: influence on intestinal microflora in healthy infants. Am J Clin Nutr 67, 111-117.

Harmsen HJM, Elfferich P, Schut F \& Welling GW (1999) A 16S rRNA-targeted probe for detection of Lactobacilli and Enterococci in faecal samples by fluorescent in Situ hybridization. Microbial Ecol Health Dis 11, 3-12.

Harmsen HJM, Wildeboer-Veloo ACM, Grijpstra J, Knol J, Degener JE \& Welling GW (2000) Development of 16S rRNAbased probes for the Coriobacterium group and the Atopobium cluster and their application for enumeration of Coriobacteriaceae in human feces from volunteers of different age groups. Appl Environ Microbiol 66, 4523-4527.

He T, Priebe MG, Vonk RJ \& Welling GW (2005) Identification of bacteria with $\beta$-galactosidase activity in faeces from lactase nonpersistent subjects. FEMS Microbiol Ecol 54, 463-469.

Hercberg S, Galan P, Preziosi P, Bertrais S, Mennen L, Malvy D, Roussel AM, Favier A \& Briancon S (2004) The SU.VI.MAX study: a randomised, placebo-controlled trial of the health effects of antioxidant vitamins and minerals. Arch Intern Med 164, $2335-2342$.

Hercberg S, Preziosi P, Briancon S, Galan P, Triol I, Malvy D, Roussel AM \& Favier A (1998) A primary prevention trial using nutritional doses of antioxidant vitamins and minerals in cardiovascular diseases and cancers in a general population: the SU.VI.MAX study-Design, methods, and participant characteristics. Control Clin Trials 19, 336-351.

Langendijk PS, Schut F, Jannsen GJ, Raangs GC, Kamphuis GR, Wilkinson MH \& Welling GW (1995) Quantitative fluorescence in situ hybridisation of Bifidobacterium spp. with genus-specific 16S rRNA-targeted probes and its application in fecal samples. Appl Environ Microbiol 61, 3069-3075.

Lay C, Sutren M, Rochet V, Saunier K, Dore J \& Rigottier-Gois L (2005) Design and validation of $16 \mathrm{~S}$ rRNA probes to enumerate members of the Clostridium leptum subgroup in human faecal microbiota. Environ Microbiol 7, 933-946.

Lepercq P, Gérard P, Béguet F, Grill JP, Relano P, Cayuela C \& Juste C (2004) Isolates from normal human intestinal flora but not lactic acid bacteria exhibit $7 \alpha$ - and $7 \beta$-hydroxysteroid dehydrogenase activities. Microbial Ecol Health Dis 16, 195-201.

Lick S, Drescher K \& Heller KJ (2001) Survival of Lactobacillus delbrueckii subsp. bulgaricus and Streptococcus thermophilus in the terminal ileum of fistulated Göttingen minipigs. Appl Environ Microbiol 67, 4137-4143.

Lowry OH, Rosebrough NJ, Farr AL \& Randall RJ (1951) Protein measurement with the Folin phenol reagent. J Biol Chem 193, $265-275$.

Macfarlane GT \& Cummings JH (1991) The colonic flora, fermentation and large bowel digestive function. In The Large Intestine: Physiology, Pathophysiology and Disease, pp. 51-92 [SF Phillips, JH Pemberton and RG Shorter, editors]. New York: Raven Press.

Manz W, Amann R, Ludwig W, Vancanneyt M \& Schleifer KH (1996) Application of a suite of 16S rRNA-specific oligonucleotide 
probes designed to investigate bacteria of the phylum cytophagaflavobacter-bacteroides in the natural environment. Microbiology 142, 1097-1106.

Marteau P, Flourie B, Pochart P, Chastang C, Desjeux JF \& Rambaud JC (1990) Effect of the microbial lactase (EC 3.2.1.23) activity in yogurt on the intestinal absorption of lactose: an in vivo study in lactase deficient humans. Br J Nutr 64, 71-79.

Marteau P \& Rambaud JC (1993) Potential of using lactic acid bacteria for therapy and immunomodulation in man. FEMS Microb Rev 12, 207-220.

Marteau P, Gerhart MF, Myara A, Bouvier E, Trivin F \& Rambaud JC (1995) Metabolism of bile salts by alimentary bacteria during transit in the human small intestine. Microbial Ecol Health Dis 8, $151-157$.

Mater DDG, Bretigny L, Firmesse O, Flores MJ, Mogenet A, Bresson JL \& Corthier G (2005) Streptococcus thermophilus and Lactobacillus delbrueckii subsp. bulgaricus survive gastrointestinal transit of healthy volunteers consuming yogurt. FEMS Microbiol Lett 250, 185-187.

Oozeer R, Furet JP, Goupil-Feuillerat N, Anba J, Mengaud J \& Corthier G (2005) Differential activities of four Lactobacillus casei promoters during bacterial transit through the gastrointestinal tracts of human-microbiota-associated mice. Appl Environ Microbiol 71, 1356-1363.

Oozeer R, Goupil-Feuillerat N, Alpert CA, van de Guchte M, Anba J, Mengaud J \& Corthier G (2002) Lactobacillus casei is able to survive and initiate protein synthesis during its transit in the digestive tract of human flora-associated mice. Appl Environ Microbiol 68, 3570-3574.

Pochart P, Dewit O, Desjeux JF \& Bourlioux P (1989) Viable starter culture, 13-galactosidase activity and lactose in duodenum after yogurt ingestion in lactase deficient humans. Am J Clin Nutr 49, $828-831$.

Rachmilewitz D, Katakura K, Karmeli F, et al. (2004) Toll-like receptor 9 signaling mediates the anti-inflammatory effects of probiotics in murine experimental colitis. Gastroenterology 126, 520-528.

Rigottier-Gois L, Le Bourhis A-G, Gramet G, Rochet V \& Dore J (2003) Fluorescent hybridisation combined with flow cytometry and hybridisation of total RNA to analyse the composition of microbial communities in human faeces using 16S rRNA probes. FEMS Microbiol Ecol 43, 237-245.

Riottot M, Olivier P, Huet A, Caboche JJ, Parquet M, Khallou J \& Lutton C (1993) Hypolipidemic effects of beta-cyclodextrin in the hamster and in the genetically hypercholesterolemic Rico rat. Lipids 28, 181-188.

Rochet V, Rigottier-Gois L, Rabot S \& Dore J (2004) Validation of fluorescent in situ hybridization combined with flow cytometry for assessing interindividual variation in the composition of human fecal microflora during long-term storage of samples. J Microbiol Methods 59, 263-270.

Rochet V, Rigottier-Gois L, Sutren M, et al. (2006) Effects of orally administered Lactobacillus casei DN-114001 on the composition or activities of the dominant faecal microbiota in healthy humans. Br J Nutr 95, 421-429.

Roos NM \& Katan MB (2000) Effect of probiotic bacteria on diarrhea, lipid metabolism and carcinogenesis: a review of papers published between 1988 and 1998. Am J Clin Nutr 71, 405-411.

Rowland IR (1992) Metabolic interactions in the gut. In Probiotics, pp. 29-53 [R Fuller, editor]. London: Chapman \& Hall.

Sanders ME (1993) Summary of conclusions from a panel of experts on health attribute of lactic cultures: significance of fluid milk products containing cultures. J Dairy Sci 76, 1819-1828.

Seksik P, Rigottier-Gois L, Gramet G, Sutren M, Pochart P, Marteau P, Jian R \& Dore J (2003) Alterations of the dominant faecal bacterial groups in patients with Crohn's disease of the colon. Gut 52, 237-242.

Shortt C (1999) The probiotic century: historical and current perspectives. Trends Food Sci Tech 10, 411-417.

Suau A, Bonnet R, Sutren M, Godon JJ, Gibson GR, Collins MD \& Dore J (1999) Direct analysis of genes encoding 16S RNA from complex communities reveals many novel molecular species within the human gut. Appl Environ Microbiol 65, 4799-4807.

Tannock GW, Munro K, Harmsen HJM, Welling GW, Smart J \& Gopal PK (2000) Analysis of the fecal microflora of human subjects consuming a probiotic product containing Lactobacillus rhamnosus DR 20. Appl Environ Microbiol 66, 2578-2588.

Teitelbaum JE \& Walker WA (2002) Nutritional impact of pre- and probiotics as protective gastrointestinal organisms. Annu Rev Nutr 22, 107-138.

Wallner G, Amann R \& Beisker W (1993) Optimizing fluorescent in situ hybridisation with rRNA-targeted oligonucleotide probes for flow cytometric identification of micro-organisms. Cytometry 14, 136-143.

Walter J, Hertel C, Tannock GW, Lis CM, Munro K \& Hammes WP (2001) Detection of Lactobacillus, Pediococcus, Leuconostoc and Weissella species in human feces by using group specific PCR primers and denaturing gradient gel electrophoresis. Appl Environ Microb 67, 2578-2585.

Yuki N, Watanabe K, Mike A, Tagami Y, Tanaka R, Ohwaki M \& Morotomi M (1999) Survival of a probiotic, Lactobacillus casei strain Shirota, in the gastrointestinal tract: selective isolation from faeces and identification using monoclonal antibodies. Int $J$ Food Microbiol 48, 51-57.

Zoetendal EG, Akkermans AD \& De Vos WM (1998) Temperature gradient gel electrophoresis analysis of 16S rRNA from human fecal samples reveals stable and host-specific communities of active bacteria. Appl Environ Microbiol 64, 3854-3859. 